\title{
THE IMPACT OF THE DECLINING PANCASILA DEMOCRACY IN THE POST- INDONESIA REFORMATION
}

\author{
Muhyar Fanani \\ FISIP UIN WALISONGO
}

\begin{abstract}
The practice of democracy post-reformation era tends to be a more "liberal" version. Since the amendment of the 1945 Constitution in 1999-2002, the politics was becoming very open. However, some experts said that Indonesian democracy after the Reformation was not the "Pancasila democracy" anymore. The objective of this study was to identify the malpractices of democracy through logical structure of Pancasila as a political ideology. The writer tried to understand the gap between the ideal and the real democratic practice in the post-Reformation era. The data in this study were collected from library, journals, and the websites. The data were analyzed in the light of Soekarno-Hatta's theory on Pancasila democracy. This study concluded that in the post-reformation Indonesia, the implementation of Pancasila democracy has been declined. The decline could be seen at malpractices of post-reformation democracy such as political oligarchy, money politics, and procedural-transactional politics. The writer recommend to Indonesian political scientists to rearrange political order based on the logical structures of Pancasila democracy through the fifth limited amendment of the 1945 Constitution. The logical structures are mufakat (full agreement, consensus), perwakilan (representativeness), and musyawarah (deliberation)
\end{abstract}

Keywords: Pancasila democracy, consensus, representativeness, deliberation

\section{INTRODUCTION}

The Reformation has great effects on many areas. Politics, economy, culture, social, security, and environment are areas that changed rapidly [1]. After the amendment of the 1945 Constitution, politics has become very open. Voting becomes very common to choose public leaders in all level of leadership [2]. Some experts said that Indonesian democracy after the Reformation is not a Pancasila democracy. It tends to be a liberal democracy[3].

As long as Pancasila becomes the national foundation, all aspects of public life in the country should be based on Pancasila [4]. Therefore, Indonesian democracy after the Reformation is still Pancasila democracy [5]. However, implementing Pancasila democracy in this era is quite hard. There are many challenges lie ahead. This paper tries to identify malpractices of Pancasila democracy implementation in the post-reformation. This identification is very important to revitalize Pancasila democracy.

\section{THE PANCASILA DEMOCRACY}

The founding fathers of Indonesia believed that democracy in Indonesia should root from the people heart [6]. Sukarno since 1920s crystallized the spirit of the people that could become the foundation of togetherness. After long and deep thinking, he found that Pancasila was the best foundation for this country.

Though democracy in Indonesia is quite promising, its quality still needs to be improved. To this day, Indonesian democracy still leaves an irony and paradox [7]. Indonesian democracy is still not fully able to meet the democratic criteria as expected by the founding fathers. Mohammad Hatta, for example, declared that democracy in Indonesia was not a liberal democracy, but Pancasila democracy [8]. What is the Pancasila democracy? Hatta wrotes:

"Democracy in the Pancasila system is not superficial democracy or democracy as a mere mask. It is a democracy which must be blessed by the One Almighty God, as the first principle of Pancasila lead throughout the ideals of our state ... Our democracy must be 
run based on truth, justice, honesty, kindness, brotherhood, and humanity. ...'[8]

Bung Hatta, as he is usually called, asserted that:

"Democracy adopted by the Indonesian nation is not a democracy that seek the most votes, but a democracy guided by the inner wisdom of deliberation among representatives. Under the frame of the One Almighty God and the basis of a just and civilized humanity, the democracy to be implemented in the country must be in accordance with truth, justice, kindness, honesty, purity, and beauty ..."[8]

Now Indonesian people are facing a test of how to create a more substantive and essential democratic practice. In this context, Hatta's statement is still relevant: "In the daily life, Pancasila is only performed at lips. Indonesian people who internalize Pancasila as a belief rooted into their heart. The people forgot that all five principles are interconnected. They don't stand separately." [9] Now Indonesian people are dealing with a lure of sheep democracy, in which the elected is the one who has large muscles (big funds from wherever source may come and control of media without limits to attack and seize power). That is what Jeffrey A. Winter called an oligarchy [10]. Can the sheep democracy produce the best and wisest leader among the candidates?

Indonesian current democracy tends to implement liberal democracy that contradicts to Pancasila and the history of the national struggle. The system of leadership recruitment is conformed with the principle of "financial almighty" and the principle of "people led by the benefit or finance". Meanwhile, Soekarno/Hatta became leaders were not because of their wealth but because of their intelligence and wisdom [11]. As the founder of Pancasila Democracy, Soekarno explains:

"For us, Indonesia nation, democracy contains three main ingredients. Democracy contains the principle called agreement, namely consensus. Second, democracy contains representation principle. Finally, democracy contains, for us, deliberation (musyawarah) principle.... From such deliberation, the consensus comes, the agreement emerges stronger than a forced resolution through majority voices...."[12]
Democracy after reformation tends to neglect the three principles of Pancasila democracy that were stipulated by Soekarno. The lack of mufakat could be seen in the big number of voting in decision making in parliament (local and national). Meanwhile, many factors could influence the result of voting especially money, capital, interest (personal, narrow, group, party) that contaminate the process of mufakat. The lack of representativeness could be seen in the absence of group delegation (utusan golongan) such as thinkers, budayawan (humanist), sastrawan (writers), seniman (artists), lectures, teachers, laborers, fishermen, and farmers. The absence of them reflects that democracy does not absorb the important voices of nation heart yet. The lack of musyawarah could be seen in many processes of meeting in parliament to decide something. The discussion tends to be in low quality, to use shallow and superficial argumentation, to neglect accurate data, to orient image projection, to choose narrow group orientation, and to neglect public interest. Meanwhile, musyawarah needs deep understanding and high commitment to build public good. Musyawarah needs hikmah (wisdom) in discussion that consists of three things, they are deep knowledge, strong commitment to build public good and bring public interest into reality, and piety. Neglecting those three principles means conducting malpractices of Pancasila democracy.

\section{MALPRACTISES OF PANCASILA DEMOCRACY}

In the post-reform era, Pancasila democracy faces malpractices that weaken good willing to implement the pure Pancasila democracy. The malpractices consist of six items; political oligarchy, money politics, procedural-transactional politics, political dynasty, political recompense, and political myopic.

\section{Political oligarchy}

Indonesia in the post-reform era tends to fall into oligarchy in the type of group oligarchy [13]. In his famous book, Jeffrey A. Winters writes that the oligarchy relies on the strength of material resources and strives for the defense of wealth in them. This situation, gradually, leads to inequalities material. Inequalities of materials produce inequality of political power. The condition occurring in Indonesia after the reform can be called a collective ruling oligarchy. This kind of oligarchy takes control collectively through institutions which have norms or rules. The oligarch, despite a minority, is able to work together maintaining wealth and ruling a huge 
group of people. The case happening in Indonesia after the reformation era is actually not something new. It also happened in Greek-Rome [10].

The oligarchy in Indonesia is not vanished at all after the fall of the New Order. It transforms from the patron-client type to the collective one. Richard Robinson and Vedi R Hadiz in Power Reorganizing in Indonesia: The Politics of Oligarchy in an Age of Market assert that the oligarchy in Indonesia has not basically ruined after the fall of Suharto. Instead, it continues to transform by adjusting with a new political context in Indonesia based on the neoliberalism philosophy, such as democratization, decentralization, and deregulation. After the economic crisis in 1998, the oligarchy with its variety survives and returns to be "a major actor" within the business world in Indonesia. Christian Chua agrees with this view. He confirms that institutional changes after the new order turn out to be exploited by the old forces to maintain "power." [14]

Oligarchy in Indonesia could not be erased by regulations. The presence of the act No.8/2015 revising a number of rules in the act No. 1/2015 (on Stipulation of Government Regulation in lieu of acts No. 1/2014 on the election of governors, regents and mayors) has not been able to address this issue. This confirms Winters' opinion that the oligarchs and oligarchy could not be removed by the change of political procedure into democracy, but rather through the equitable distribution of material resources. Reducing oligarchy means not to give a big political power to the little number of people [15].

\section{Money politics}

Another malpractice of Pancasila democracy is money politics. Many political parties in Indonesia prefer to choose the short way in gaining voters by giving money to them. Why? This is caused by the weakness of the internal political party especially in breeding, communication, and building public trust. The weak parties' performances result in the candidates stuck in a vicious circle of political recompense. This drives the parties' candidates who sit in the parliament are caught in various cases of corruption, bribery and abuse of power [16]. To meet the high cost of elections and to run the activities of political parties, they get forced to look for illicit funds. [17]

\section{Procedural-transactional politics}

Next malpractice of Pancasila democracy is procedural-transactional politics. Oligarchy leads to political power controlled by a group of capital owners who have different interests and try to hostage each other. These strategic positions are occupied by people who can give advantages to the capital owners [17]. When public positions are obtained by political dealings between the president and supporting political parties, the policy will advantageously turn to the parties and ignore the "sacred" duties of the state and democracy.

Manuel Luis Quezon emphasizes that "My loyalty to my party ends when my loyalty to my country begins." In essence, a political party is merely a vehicle to deliver its cadres for "jihad" promoting and struggling for the interests of people represented, not the interests of the parties' elites only [18]. Therefore, the procedural-transactional democracy should be abolished.

\section{Political dynasty}

The further malpractice is political dynasty. Post reform Indonesia paves the ways for certain dynasty to buy votes because the dynasty has wealth and prosperity to do so. It confirms a statement of Robert Michel that leaders in a democratic organizational leadership, tend to grip power and undermine democratic principles. This is called as the iron law of oligarchy [19]. In line with Michel, Putnam also reminds that the elites of politics who are in power tend to keep perpetuating themselves in power (selfperpetuating) although it results in the decay of their institutions [19].

Why can this political dynasty grow in a democracy? Inge Amundsen and Nico Harjanto explain that the weakness of political parties in carrying out the regeneration function, selection and promotion, leads to the emergence of such political dynasty. Therefore, to remove political dynasty, supervision and law enforcement which is frightening have to be done. Another important step is to strengthen the institution of political parties as well as to expand the number of intelligent voter [20].

\section{Political recompense}

The very high cost of post-reform politics in Indonesia gets cadres drowned. When people are about to drown, they will hold anything they can in order to rise and survive. With the holding, the drowning person will survive. The problem is whether the helper is a good person or a bad person. When meeting the good one, they are lucky. But when the helper is just like an evil capital owner, the drowning person will be safe, but they will fall into a slavery of the capital owners. They will be like figureheads with no spirit and soul. They will get stuck on the endless political recompense. From 
Sabang to Merauke, indications of this type of politics become increasingly evident. There is no other compensation except money, position and work contract in exploiting natural resources. The implementation of acts on regional autonomy policy makes "the game" easier for politicians to play.

\section{Political myopic}

Poor quality of cadres in political parties causes the emergence of political myopic. The politicians become "short-sighted." They are no longer able to look far into the future. They are only able to see things for their short term. More terribly, they can only see the material objects. The nation's idealism, the nation founding fathers' idealism, and the nation's interest for, let us just say, the next 30 years cannot be seen.

Signs of political myopic have been already apparent. Look at the legislation system in post reform era of this country. Legislative process is run by the cowtrading strategies. The legislative process should not be guided by pragmatic interests which takes place on a transactional basis. Mahfud MD stated that the cow-trading legislation is a real phenomenon. At the beginning of the reformation era, the process of legislation drafting was actually financed by foreigners. As a result, a lot of acts are nuanced by liberal values in favor of foreign interests. For example, there are acts on oil and gas, acts on minerals, energy, and coal (mining), and some other acts, all of which is contrary to the article 33 of the 1945 Constitution and the basic principles and purposes of this nation [21].

To overcome those problems, Indonesian people must revitalize Pancasila democracy into 1945 Constitution through the next amendment. At least, there are four points of the last-four-amendment results that are not in accordance with Pancasila philosophy as a driving value of the nation, namely leadership unaccountability, absence of group delegation in MPR, problem of original Indonesian citizen, and high cost politics. Then, the next amendment is needed to make sure that the democracy in Indonesia performs the forth principle of Pancasila.

\section{CONCLUSION}

The discussion above shows that after reformation, the implementation of Pancasila democracy tends to decline. The impact of the decline is the emergence of some malpractices of Pancasila democracy. As long as Pancasila as the state philosophy was agreed, all regulations in Indonesia must refer to it including the 1945 Constitution Amendment. Some malpractices in the implementation of the 1945 Constitution Amendment should become a basis to redesign Indonesian politics in order to be compatible with the values of the nation's majesty.

Implementation of the values of Pancasila democracy into the fifth amendment of 1945 Constitution is an important priority. This heavy task cannot certainly be delivered to whoever does not have the majesty of nation. Arabic proverb says "Faqidusy Syai' la $y u^{\prime}$ thi" (people who do not have anything, would not be able to give something). Let us ask, could this nation distinguish between gold and pan? The answer was actually clear. However, as a result of money politics in the campaign, the war of printed / electronic media that had been a very liberalcapitalistic, the weaknesses of punishment to any violations of campaign regulation, a little number of educated and enlightened people, and a huge number of hungry people, then, the condition was not a normal condition. Building a system to make only the wise people who can sit in DPR and MPR is very urgent. They sat there not because of their wealth, but because of their wisdom. Therefore, the system that performs three principles namely consensus, representativeness, and deliberation must be implemented soon

\section{References}

[1] Freedman, Amy L., Political Change and Consolidation: Democracy's Rocky Road in Thailand, Indonesia, South Korea, and Malaysia. New York: Palgrave Macmillan, 2006

[2] Ghashal, Baladas, "Political Development in Post-Soeharto Indonesia", Contemporary Sotheast Asia 26, no.3 (2004): 506-29.

[3] Iqbal, Mahathir Muhammad, "Demokrasi Ersatz: Menggugat Peran Pemuda dalam Mengawal Proses Demokratisasi di Indonesia", Sosio Didaktika: Social Science Education Journal, 2 (2), (2015): 147-55.

[4] Ramage, Douglas E., Politics in Indonesia: Democracy, Islam and the Ideology of Tolerance. London and New York: Rotledge. 1995.

[5] Kaban, Roman, "Perkembangan Demokrasi di Indonesia", Perspektif vol VII, no. 3 (Juli 2000): 158-69.

[6] Latif, Yudi, Negara Paripurna: Historisitas, Rasionalitas, dan Aktualitas Pancasila. Jakarta: PT Gramedia, 2015 
[7] Sebastian, Leonard C., "The Paradox of Indonesian Democrcay", Contemporary Southeast Asia 26, no. 2 (2004): 256-79

[8] Pane, Nina (Ed.), Mohammad Hatta, Politik, Kebangsaan, Ekonomi (1926-1977). Jakarta: Kompas, 2015

[9] Hatta, Muhammad, Pengertian Pancasila. Jakarta: Idayu Press, 1977

[10] Winters, Jeffrey A., Oligarchy. Illinois: Cambridge University Press, 2011

[11] Pane, Nina, Mohammad Hatta : Memoir. Jakarta: PT. Tintamas Indonesia, 1979

[12] Soekarno, "Membangun Dunia Kembali, Pidato Presiden RI di Muka Sidang Umum PBB ke XV, 30 September 1960" dalam Soekarno, Membangun Dunia Kembali.

[13] Savirani, Amalinda, and Olle Tornquist (ed.), Reclaiming the State: Overcoming Problems of Democracy in Post-Soeharto Indonesia. Yogyakarta: Penerbit PolGov, 2015.

[14] Chua, Christian, "Capitalist Consolidation, Consolidated Capitalist: Indonesia's Conglomerates between Authoritarianism and Democracy" dalam Marco Bunte and Andreas Ufen (ed), Democratization in Post-Soeharto Indonesia.

[15] Winters, Jeffrey A, "Oligarki dan Demokrasi di Indonesia", Prisma, Vol. 33 No. 1 Tahun 2014

[16] Ganie-Rochman, Meauthia and Rochman Achwan, "Corruption in Indonesia's Emerging Democracy" Journal of Developing Societies 32, 2 (2016): 15977.

[17] Hara, Abubakar E., "The Difficult Journey of Democratization in Indonesia" Contemporary Southeast Asia, vol: 23, no. 2, (Agust 2001): 307-26.

[18] Internet website: http://geotimes.co.id/saatnyamereformasi-partai-politik/

[19] Kristiadi, J., "Politik Dinasti, Sebab atau Akibat?", Harian Kompas edisi 21 Juli $2015,15$.

[20] Kompas, 12 Januari 2011; http://www.antikorupsi.org/id/content/din asti-politik-kian-menguat

[21] Internet website:

http://www.tribunnews.com/nasional/2013/12/07/ma

hfud-md-indonesia-terjebak-demokrasi-prosedural 